\title{
Effects of Clean and Strip Cultivation, and of Mulching with Grass, Coffee Pulp, and Black Plastic, on Yields of Intensively Managed Coffee in Puerto Rico
}

\section{José Vicente Chandler, Elvin Boneta, Fernando Abruña, and Jacinto Figarella ${ }^{2}$ \\ INTRODUCTION}

The steep coffee lands must be protected from erosion if high yields are to'be produced continuously, and siltation of Puerto Rico's vital reservoirs prevented. Excellent soil protection can be attained by planting the coffee trees close together in contour rows with a strip of grass between rows. Mulching under the coffee rows may further protect the soil from erosion and increase coffee yields.

In Africa $(1,2,3)^{3}$ grass mulches generally increase and strip cultivation generally decreases coffee yields in areas with a marked dry season. In Brazil (4) well-fertilized coffee growing in full sunlight responded strongly to mulching. No information was found in the literature on the effects of plastic mulching on coffee. There is very little information available on the effects of either mulching or strip cultivation on yields of coffee in Puerto Rico.

The present study was carried out to determine the effect of clean and strip cultivation, and of mulching with grass, coffee pulp, or black plastic under the coffee rows, on yields of intensively managed, heavily fertilized coffee growing in full sunlight.

\section{MATERIALS AND METHODS}

The experiment was carried out at the Adjuntas Substation of the Agricultural Experiment Station, Mayagüez Campus, of the University of Puerto Rico. This substation is at an elevation of about 2,000 feet, with a mean annual temperature of about $75^{\circ} \mathrm{C}$. and annual rainfall of about 68 inches, with a marked dry season from January through March.

1 This paper covers work carried out cooperatively between the Soil and Water Conservation Research Division, Agricultural Research Service, USDA, and the Agricultural Experiment Station of the Mayagüez Campus of the University of Puerto Rico, in Río Piedras, P.R.

2 Project Leader-Research Soil Scientist, Soil and Water Conservation Research Division, Agricultural Research Service, USDA; Assistant Horticulturist, Agricultural Experiment Station of the Mayagüez Campus of the University of Puerto Rico; and Research Soil Scientist and Chemist, Soil and Water Conservation Research Division, Agricultural Research Service, USDA, respectively.

Italic numbers in parentheses refer to Literature Cited, p. 131. 
The soil is Limani clay with 4.1-percent organic matter, 0.2-percent nitrogen, a $\mathrm{pH}$ of 4.9 , and an exchange capacity of 16.2 meq., with 4.4 meq. of exchangeable bases per $100 \mathrm{~g}$. of soil. The surface soil has excellent physical condition (bulk density 1.1), but the subsoil has a blocky structure and relatively low permeability.

The following treatments were tested:

1. Clean cultivation,

2. Grass strip between coffee rows with clean cultivation under trees,

3. Grass strip between coffee rows with coffee pulp under trees,

4. Grass strip between coffee rows with Guinea grass mulch under trees,

5. Grass strip between coffee rows with black plastic mulch under trees.

Mulches were applied to a strip 2 feet wide on each side of the coffee rows. Approximately 4 inches of organic mulch were maintained under the coffee rows in treatments 3 and 4 . Clean-cultivated areas were weeded as required and grass strips between rows were mowed whenever they attained a height of about 1 foot.

All treatments were replicated four times in a randomized block design. Individual plots were 16 by 30 feet, with 12 trees of the semidwarf Caturra variety per plot. Trees were planted in 3 rows 10 feet apart, with trees 4 feet apart in the rows. The coffee trees were transplanted to the field in September 1963, were protected against pests and disease by periodic spraying, and were otherwise well cared for during the course of the experiment.

The soil was limed to $\mathrm{pH} 5.5$ by applying 4 tons of limestone per acre. Five hundred pounds of 12-6-16 fertilizer containing 300 pounds of magnesium sulfate and 20 pounds of a complete minor-element mixture per ton were applied per acre in three equal applications during the first year. One ton of this fertilizer was applied per acre during the subsequent year and 3,000 pounds during the following years. The fertilizer was applied in three equal applications in April, July, and October of each year.

Yields produced by each plot were determined by picking the berries as they ripened. Yields of market coffee were calculated, assuming that 28 pounds of berries produced $41 / 2$ pounds of market coffee.

Leaf samples (third pair of leaves from the branch tips) were taken periodically from the six trees in the center of each plot and analyzed for $\mathrm{N}, \mathrm{P}, \mathrm{K}, \mathrm{Ca}, \mathrm{Mg}$, and $\mathrm{Mn}$.

Soil samples were taken to a depth of 1 foot under the coffee rows in all plots during the middle of one wet (August 1964) and one dry (March 1965) season, and their water content determined.

Soil temperatures were taken at various depths in each plot near noon on a cloudless day in July 1965, using a standard soil thermometer. 


\section{RESULTS AND DISCUSSION}

Table 1 shows that annual rainfall at the experimental site ranged from 65.3 to 74.3 inches, and monthly rainfall from 0.5 to 19.8 inches. The coffee

TABLs 1.-Monthly rainfall (inches) at the Adjuntas Substation, 1964-67

\begin{tabular}{l|r|r|r|r}
\hline \multicolumn{1}{c|}{ Month } & 1964 & 1965 & 1966 & 1967 \\
\hline January & 1.8 & 0.9 & 0.8 & 3.8 \\
February & 2.2 & .5 & 1.0 & 3.5 \\
March & 1.4 & 1.1 & 3.4 & 1.6 \\
April & 1.8 & 8.6 & 8.0 & 2.9 \\
May & 1.6 & 14.9 & 9.0 & 1.0 \\
June & 5.4 & 6.6 & 2.9 & 5.1 \\
July & 5.1 & 5.8 & 7.5 & 3.5 \\
August & 8.8 & 5.3 & 7.5 & 19.4 \\
September & 12.6 & 6.2 & 13.7 & 10.3 \\
October & 19.8 & 5.7 & 12.7 & 7.2 \\
November & 2.1 & 5.7 & 4.5 & 3.6 \\
December & 2.7 & 8.2 & 3.3 & 4.6 \\
\multicolumn{1}{c}{ Total } & 65.3 & 69.5 & 74.3 & 66.5 \\
\hline
\end{tabular}

TABLE 2.-Effect of clean-and strip-cultivation and of various mulches on available water in the upper foot of soil, under intensively managed sun-grown coffee during the middle of wet and dry seasons at Adjuntas ${ }^{2}$

\begin{tabular}{|c|c|c|}
\hline \multirow{2}{*}{ Treatments } & \multicolumn{2}{|c|}{ Available soil water (inches) } \\
\hline & Wet season 1964 & Dry season 1965 \\
\hline 1. Clean cultivation & 1.7 & 0 \\
\hline $\begin{array}{l}\text { 2. Grass strip between coffee rows with } \\
\text { clean cultivation under trees }\end{array}$ & 2.1 & .1 \\
\hline $\begin{array}{l}\text { 3. Grass strip between coffee rows with } \\
\text { coffee pulp under trees }\end{array}$ & 3.9 & .9 \\
\hline $\begin{array}{l}\text { 4. Grass strip between coffee rows with } \\
\text { grass mulch under trees }\end{array}$ & 3.2 & .8 \\
\hline $\begin{array}{l}\text { 5. Grass strip between coffee rows with } \\
\text { black plastic mulch under trees }\end{array}$ & 2.4 & .4 \\
\hline
\end{tabular}

1 Water retained at pressures between $1 / 3$ and $15 \mathrm{~atm}$.

2 Samples were taken in the coffee rows. Values are averages of 4 replications.

trees suffered visibly from drought during much of the marked dry season from January through March.

Table 2 shows that there was more soil water available for plant growth under both coffee-pulp and grass mulches during the middle of both dry and wet seasons. The coffee pulp and grass mulches probably enhanced 
infiltration of rain water, and reduced water losses through evaporation. There was no water available in the upper foot of soil under the coffee rows for plant growth in either the clean or strip cultivated plots during the middle of the dry season.

TABLE 3.-Effect of various soil covers on soil temperature at noon on a cloudless day in July $1966^{1}$

\begin{tabular}{|c|c|c|c|c|c|}
\hline \multirow{2}{*}{ Soil cover } & \multicolumn{5}{|c|}{ Temperature at soil depth (inches) } \\
\hline & 1 & 2 & 3 & 4 & 6 \\
\hline & $\cdot F$ & $\cdot \vec{P}$ & $\cdot F$ & ${ }^{\circ} \mathrm{F}$ & ${ }^{\circ} B$ \\
\hline 1. Bare unshaded soil between coffee rows & 95 & 93 & 90 & 86 & 81 \\
\hline 2. Bare soil shaded by coffee trees & 82 & 79 & 77 & 77 & 75 \\
\hline 3. Soil under 4 inches of tall grass strip & 85 & 82 & 81 & 79 & 77 \\
\hline 4. Soil under coffee-pulp mulch & 79 & 77 & 75 & 75 & 72 \\
\hline 5. Soil under grass mulch & 79 & 77 & 75 & 75 & 73 \\
\hline 6. Soil under black plastic mulch & 97 & 93 & 88 & 85 & 81 \\
\hline
\end{tabular}

${ }^{1}$ All values are averages of 4 replicate plots with 3 readings taken in each plot.

TABLE 4.-Effect of clean- and strip-cultivation, and of various mulches on foliar composition of intensively managed Caturra coffee growing in full sunlight at Adjuntas'

\begin{tabular}{|c|c|c|c|c|c|c|}
\hline \multirow{2}{*}{ Treatments } & \multicolumn{6}{|c|}{ Composition of coffee leaves on dry-weight basis } \\
\hline & $\mathbf{N}$ & $\mathbf{P}$ & $\mathbf{K}$ & $\mathrm{Ca}$ & $\mathbf{M g}$ & Mn \\
\hline & Percent & Percent & Percent & Percent & Percent & p.p.s.n. \\
\hline 1. Clean cultivation & 3.14 & 0.11 & 1.83 & 1.21 & 0.39 & 663 \\
\hline $\begin{array}{l}\text { 2. Grass strip between coffee rows with } \\
\text { clean cultivation under trees }\end{array}$ & 3.06 & .11 & 2.06 & 1.19 & .32 & 804 \\
\hline $\begin{array}{l}\text { 3. Grass strip between coffee rows with } \\
\text { coffee pulp under trees }\end{array}$ & 3.13 & .13 & 2.49 & 1.27 & .29 & 471 \\
\hline $\begin{array}{l}\text { 4. Grass strip between coffee rows with } \\
\text { grass mulch under trees }\end{array}$ & 3.09 & .12 & 2.32 & 1.13 & .28 & 570 \\
\hline $\begin{array}{l}\text { 5. Grass strip between coffee rows with } \\
\text { black plastic mulch under trees }\end{array}$ & 2.88 & .10 & 1.86 & 1.31 & .36 & 533 \\
\hline
\end{tabular}

1 Values are averages of 4 replications and 4 sampling dates (March 1965-September 1965, July 1966, and March 1967).

Table 3 shows that soil temperatures were relatively high in the bare soil, decreasing gradually with depth. Soil temperatures under the black plastic mulch were very similar to those in bare soil. Both shade of the coffee trees and of the grass cover between coffee rows reduced soil temperature considerably. The grass and coffee-pulp mulches reduced soil temperatures markedly and identically at all depths in the soil. 
Table 4 shows that nutrition of the coffee trees was adequate for the production of high yields as compared with generally accepted levels, with the possible exception of phosphorus. The treatments did not markedly affect the $\mathrm{N}, \mathrm{P}, \mathrm{Ca}, \mathrm{Mg}$, or $\mathrm{Mn}$ content of the coffee leaves in any of the four sampling dates. $K$ content of the coffee leaves in the coffee-pulp and grassmulched plots was slightly higher than in the other treatments. Mn content of the coffee leaves was high in all cases, occasionally approaching what are considered toxic levels.

Table 5 summarizes yield data obtained over 3 consecutive years. During the first crop-year (1965) mulching with coffee pulp or grass increased

TABLE 5.-Effect of clean-and strip-cullivation, and of various mulches on yields of intensively managed Caturra coffee growing in full sunlight at Adjuntas over the first 8 crops after planting

\begin{tabular}{l|c|c|c|c}
\hline \multicolumn{1}{c|}{ Treatments } & \multicolumn{2}{|c|}{ Yields of market coffee (pounds/acre)' } & \multirow{2}{*}{ Averages } \\
\cline { 2 - 3 } & 1965 & 1966 & 1967 & \\
\hline $\begin{array}{l}\text { 1. Clean cultivation } \\
\text { 2. Grass strip between coffee rows with } \\
\text { clean cultivation under trees }\end{array}$ & $\begin{array}{c}1,080 \mathrm{bc} \\
859 \mathrm{c}\end{array}$ & $\begin{array}{c}1,133 \mathrm{a} \\
875 \mathrm{ab}\end{array}$ & $\begin{array}{c}1,070 \mathrm{~b} \\
885 \mathrm{~b}\end{array}$ & $\begin{array}{c}1,094 \mathrm{ab} \\
873 \mathrm{~b}\end{array}$ \\
$\begin{array}{l}\text { 3. Grass strip between coffee rows with } \\
\text { coffee pulp under trees }\end{array}$ & $1,596 \mathrm{a}$ & $855 \mathrm{ab}$ & $1,698 \mathrm{a}$ & $1,383 \mathrm{a}$ \\
$\begin{array}{l}\text { 4. Grass strip between coffee rows with } \\
\text { grass mulch under trees }\end{array}$ & $1,337 \mathrm{ab}$ & $165 \mathrm{c}$ & $1,202 \mathrm{ab}$ & $901 \mathrm{~b}$ \\
$\begin{array}{l}\text { 5. Grass strip between coffee rows with } \\
\text { black plastic mulch under trees }\end{array}$ & $953 \mathrm{bc}$ & $461 \mathrm{bc}$ & $741 \mathrm{~b}$ & $718 \mathrm{~b}$ \\
\hline L.S.D. 5 percent & 435 & 560 & 593 & 417 \\
\hline
\end{tabular}

1 Values having one or more letters in common do not differ significantly.

yields of strip cultivated coffee (treatments 3 and 4 vs. 2), but mulching with black plastic did not affect yields significantly (treatment $5 v s .2$ ). Strip-cultivated plots produced as high yields as did those under clean cultivation (treatment 2 vs. 1).

During the second crop year (1966) mulching with coffee pulp or black plastic did not affect yields of strip-cultivated coffee (treatments 3 and 5 vs. 2). Mulching with grass, on the other hand, resulted in much lower yields of coffee (treatment $4 \mathrm{vs}$. 2). Strip-cultivated plots continued to produce as high yields as did those with clean cultivation (treatment 1 v8. 2).

During the third crop year (1967) mulching with coffee pulp increased yields of strip-cultivated coffee (treatment 3 vs. 2), but mulching with grass (treatment 4 vs. 2) or black plastic (treatment 5 vs. 2) did not increase 
yields. As in previous years, strip-cultivated plots produced as high yields as did those with clean-cultivation (treatment 2 vs. 1).

Yields of both clean- and strip-cultivated coffee varied little from year to year, but yields of mulched coffee varied widely. The grass-mulched trees in particular exhibited severe symptoms of dieback ${ }^{4}$ following the heavy 1965 crop and this was reflected in the very low yields produced in 1966.

Averages for the three crop years show that application of coffee-pulp mulch sharply increased yields of strip-cultivated coffee from an average of 873 to 1,383 pounds per acre (treatment $2 v s$. 3). Coffee pulp was superior to grass (901 pounds) or black plastic (718 pounds); which did not increase yields of strip-cultivated coffee (treatment 2 vs. 4 and 5). Strip-cultivated plots produced as high yields as did clean-cultivated plots (treatments 1 vs. 2).

Table 5 shows that a strip of grass can be maintained between coffee rows to control erosion without affecting yields, even with young coffee trees in areas with a relatively marked dry season. With older trees, and in areas of higher rainfall typical of much of the Coffee Region, there is little danger of decreasing yields by strip cultivation.

Mulching with black plastic or with grass under the coffee rows, an expensive practice, helped to control weeds, but had little effect on yields.

Grass-mulched plots produced as high yields as did plots mulched with coffee pulp during the high-yield years of 1965 and 1967, but yields of the grass-mulched plots dropped disastrously in 1966 following widespread dieback after the heavy 1965 crop. The reasons for this sharp drop in yields are not clear, since the grass mulches kept the soil as moist and cool as did coffee pulp, and there was no sharp difference in foliar composition of the coffee trees. Possibly the decomposing grass mulch of low nutrient content tied up vital nutrients during critical periods for the coffee trees, or produced substances toxic to the latter.

Coffee-pulp mulch probably increased yields through a combination of factors, i.e., increased available soil water, kept the surface soil cool, and provided a continuous supply of nutrients.

Applications of coffee pulp as a mulch under the coffee rows increased yields by an average of 510 pounds of market coffee per acre yearly worth about $\$ 347$ at the local price of $68 \notin$ per pound. Picking and processing costs totaled $\$ 127$ and cost of applying the required 20 tons or so of coffee pulp is estimated at $\$ 50$ under favorable conditions, leaving a profit of about $\$ 170$ per acre from mulching.

Furthermore, 20 tons of coffee pulp contain approximately 200 pounds of $N, 280$ pounds of $K$, and 34 pounds of $P$, enough to supply the nutrient

- A physiologic condition of coffee induced by a shortage of carbohydrates or by mineral or water deficiencies when an excessively heavy crop of berries is maturing. 
requirements of high-yielding coffee. However, these nutrients are only slowly released through decomposition, and therefore cannot fully meet the needs of the coffee trees. Nevertheless, considerable savings in fertilizer costs are possible with coffee mulched with coffee pulp. Savings in cultivation costs are also possible.

However, the supply of coffee pulp is limited. About 2 tons of coffee pulp are produced per ton of market coffee. Thus, it takes 10 acres of coffee producing 1 ton of market coffee per acre, or 100 acres of average coffee yielding 200 pounds per acre, to provide mulch for 1 acre of coffee.

Furthermore, the experimental data are limited to fairly young coffee trees growing in an area with a marked dry season. Older coffee trees, which almost completely shade the ground, growing under higher rainfall conditions typical of much of the coffee region possibly benefit less from mulching.

Thus, applications of a coffee-pulp mulch appear best suited to areas with a marked dry season, with young trees, and on gentle slopes where application costs can be kept low. Snails are sometimes a problem with young, mulched coffee trees, and must be controlled as soon as damage is observed.

\section{SUMMARY}

The effects of clean- and strip-cultivation, and of applications of coffee pulp, grass, and balck-plastic mulches under rows of heavily fertilized, young, intensively managed, strip-cultivated coffee growing in an area with a marked dry season were determined.

Mulching with coffee pulp or grass increased soil water available to the coffee trees during the dry season and sharply reduced surface soil temperatures. The treatments had no marked effect on foliar composition of the coffee trees.

Mulching with coffee pulp increased yields of strip-cultivated coffee over 3 bearing years from an average of 873 to 1,383 pounds of market coffee per acre yearly, but mulching with grass or black plastic did not affect yields. Strip-cultivated coffee produced as high yields as did clean-cultivated coffee. Yields of mulched coffee varied more widely from year to year than did those of clean or strip-cultivated coffee.

Applications of coffee pulp as a mulch may be warranted on limited acreages of young, intensively managed coffee growing in full sunlight, particularly in regions with a marked dry season. Other mulch material is not readily available in the Coffee Region.

\section{RESUMEN}

En un experimento con cafetos jovenes, manejados intensivamente a pleno sol, se compararon los efectos del cultivo limpio, del cultivo en franjas, 
y del uso de las aplicaciones de pulpa de café como cubierta, de cubiertas plásticas y de cubiertas de yerba picada, bajo las hileras de cafetos.

El uso de la pulpa o de la yerba como cubiertas, aumentaron la humedad disponible para los arbustos durante la época de sequía y además disminuyeron la temperatura de la superficie del suelo. Sin embargo, estas cubiertas no alteraron la composición química foliar de los arbustos.

El uso de la pulpa como cubierta aumentó los rendimientos durante 3 años consecutivos, de un promedio anual de 875 a 1,383 libras de café pilado por cuerda. La cubierta plástica y la de yerba picada no tuvieron efecto alguno sobre la producción. La siembra en franjas produjo rendimientos similares a los del sistema de cultivo limpio. Se observó una variación mayor en la producción anual de las parcelas con cubiertas de pulpa, de yerba o plásticas, que en los sistemas de cultivo limpio o en franjas.

El uso de la pulpa de café como cubierta parece aconsejable solo en extensiones limitadas de cafetos jóvenes cultivados intensivamente a pleno sol, especialmente en aquellas áreas con periodos de sequía definidos.

\section{LITERATURE CITED}

1. Haarar, A. E., Modern Coffee Production, Leonard Hill Ltd. London, England, 1956.

2. Keen, B., Crop Responses to Fertilizers and Manures in East Africa, The East Afri. Agric. J. 19: 1957.

3. Maidment, W., Mulch and Shade Demonstration Plots of Uganda Coffee, Uganda Dept. of Agr., Annual Report, June 1945.

4. Medcalf, J. C., Preliminary Study on Mulching Young Coffee in Brazil, Bull. 12, IBEC Research Institute, 30 Rockefeller Plaza, N.Y. 20, N.Y. 